\title{
Genetic Variability, Character Association and Path Analysis of Seed Yield and Its Contributing Traits in Field pea (Pisum sativum L. var. arvense)
}

\author{
Kanhaiya Lal", Rajesh Kumar, Shiv Prakash Shrivastav, \\ Ashok Kumar and Yogendra Singh
}
Department of Genetics and Plant Breeding, Narendra Deva University of Agriculture and Technology, Kumarganj, Faizabad-224 229 (U.P.), India

*Corresponding author

\begin{tabular}{|l|}
\hline K e y w o r d s \\
$\begin{array}{l}\text { Field pea (Pisum sativum } \\
\text { L. var. arvense), Genetic } \\
\text { variability, Character } \\
\text { association and Path } \\
\text { coefficient }\end{array}$ \\
\hline Article Info \\
\hline $\begin{array}{l}\text { Accepted: } \\
\text { 18 May 2018 } \\
\text { Available Online: } \\
\text { 10 June } 2018\end{array}$ \\
\hline \hline
\end{tabular}

\section{A B S T R A C T}

One hundred twenty field pea (Pisum sativum L. var. arvense) genotypes were evaluated with four check varieties viz., Ambika, Rachna, HFP 8909 and HUDP 15 to assess the genetic variability, association of different yield traits and direct $\&$ indirect effects of these traits on seed yield. Analysis of variance (ANOVA) revealed significant differences among all the genotypes for majority of the traits except number of primary branches per plant. The genotypes showed moderate to high level of genotypic coefficient of variance (GCV) and phenotypic coefficient of variance (PCV). The magnitudes of phenotypic coefficient of variance (PCV) for all the characters were slightly higher than their corresponding genotypic coefficient of variance $(\mathrm{GCV})$, indicated very less environmental influence on the expression of the characters. Higher estimate of GCV (30.414) was recorded for number of seeds per pod followed by seed yield per plant (28.874). Correlation analysis indicated that seed yield per plant exhibited highly significant and positive correlation with harvest index, seeds per pod, pod length and 100-seed weight. Path analysis indicated that the highest positive and direct effect on seed yield per plant was exerted by harvest index and seeds per pod. Highly positive indirect effect on seed yield per plant was exerted by harvest index via seeds per pod, pod length and biological yield per plant. The characters identified above as important direct and indirect yield components can be used in formulation of selection strategy in field pea for selection of high yielding genotypes.

\section{Introduction}

Field pea (Pisum sativum L. var. arvense), is one of the most important pulse crops of India. It grows in winter season and belongs to tribeVicieae, order-Fabales, family-Leguminoceae (Fabaceae), sub-family-Papilionaceae, genusPisum and species-sativum having chromosomes, $2 \mathrm{n}=2 \mathrm{X}=14$. Pea has versatile uses as food, feed and fodder. Pea (Pisum sativum L.) besides pulse, residues are nutritious feed for livestock and milch cattle and thus, offer an added advantage to the poor farmer families. There are two types of pea grown in India viz., vegetable type in which grains are very sweet when green and become wrinkled on drying and grain type where grains are generally dull white and round. 
Green seeds of the grain type are not as sweet as vegetable type. The dry grains are consumed in various forms such as chat, chhola, dal, vegetable and flour. Green seeds are used as fresh, frozen or canned vegetable. Despite the inherent high productivity potential of pea, its production has been on decline and average productivity is miserably low, due to non-availability of input responsive, biotic and abiotic stress resistant varieties. Therefore, there is an urgent need to evolve high yielding varieties having high protein content and resistance to major biotic and abiotic stresses with suitability for different agro-climatic conditions and cropping systems. Since the scope of genetic improvement in any crops depends mainly on the extent of available genetic variability, this study was done to assess the genetic variability, association of different seed yield traits and direct \& indirect effects of these traits on seed yield.

\section{Materials and Methods}

This study was designed to work out the status of genetic variability, association of different seed yield traits and direct \& indirect effects of these traits on seed yield among one hundred twenty field pea genotypes with four check varieties viz., Ambika, Rachna, HUDP 15 and HFP 8909during Rabi 2015-16 at Genetics and Plant Breeding Research Farm of Narendra Deva University of Agriculture and Technology, Narendra Nagar, Kumarganj, Faizabad (U.P.).The seeds of different genotypes were available with Pulses Section of the University. The experiment was laid out in Augmented Block Design.

The entire experimental field was divided into 12 blocks of equal size and each block had 14 plots. Out of 14 plots in a block, 10 plots were used for accommodating the un-replicated test genotypes while 4 were allocated to the four check varieties. The four checks were randomly allocated along with the test genotypes in a block. Each plot consisted of a single row of $4 \mathrm{~m}$ length, following inter and intra row spacing $30 \mathrm{~cm}$ and $10 \mathrm{~cm}$ respectively. Recommended cultural practices were practiced to raise a good crop. The observations were recorded on randomly selected five competitive plants from each genotype for nine characters viz. Plant height $(\mathrm{cm})$, number of primary branches per plant, number of pods per plant, pod length $(\mathrm{cm})$, number of seeds per pod, 100-seed weight, biological yield per plant, harvest index and seed yield per plant $(\mathrm{g})$, while two characters viz., days to 50 per cent flowering, days to maturity were recorded on the plot basis. The analysis of variance for augmented block design (Federer 1956), GCV and PCV (Burton and de Vane 1953), correlation coefficient (Searle 1961), path coefficient (Dewey and Lu 1959) were estimated.

\section{Results and Discussion}

The analysis of variance revealed highly significant differences among all the genotypes for all the characters under study except number of primary branches per plant, it indicated that high amount of variability was present among all the genotypes (Table 1). Phenotypic coefficient of variance (PCV) was higher than genotypic coefficient of variance (GCV), which indicated the effect of environment on the expression of characters (Table 2). Bashir et al., (2017) and Meena et al., (2017) also reported that relative magnitude of phenotypic coefficients of variation was higher than genotypic coefficients of variation for all the characters under study indicating environmental influence on the traits. Kumar (2008), Khan et al., (2017), Pal and Singh (2012) and Ranjan et al., (2006) also found that the genotypes differed significantly for all the traits except the number of branches per plant. Higher estimate of GCV was recorded for number of seeds per pod (30.414) followed by seed yield per plant (28.874). 
Table.1 Analysis of variance of augmented block design for 11 characters in field pea genotypes

\begin{tabular}{|c|c|c|c|c|c|c|c|c|c|c|c|c|}
\hline S.V. & d f & $\begin{array}{c}\text { Days of } \\
50 \text { per } \\
\text { cent } \\
\text { flowering }\end{array}$ & $\begin{array}{l}\text { Days to } \\
\text { maturity }\end{array}$ & $\begin{array}{l}\text { Plant } \\
\text { height } \\
\text { (cm) }\end{array}$ & $\begin{array}{c}\text { Number } \\
\text { of pods/ } \\
\text { plant }\end{array}$ & $\begin{array}{c}\text { Pod } \\
\text { length } \\
(\mathrm{cm})\end{array}$ & $\begin{array}{c}\text { Number } \\
\text { of } \\
\text { primary } \\
\text { branches/ } \\
\text { plant }\end{array}$ & $\begin{array}{c}\text { Number } \\
\text { of seeds/ } \\
\text { pod }\end{array}$ & $\begin{array}{l}\text { 100- Seed } \\
\text { weight (g) }\end{array}$ & $\begin{array}{l}\text { Biologic } \\
\text { al yield/ } \\
\text { plant (g) }\end{array}$ & $\begin{array}{l}\text { Seed } \\
\text { yield } \\
\text { /plant } \\
\text { (g) }\end{array}$ & $\begin{array}{c}\text { Harvest } \\
\text { index } \\
(\%)\end{array}$ \\
\hline $\begin{array}{l}\text { Blocks (ignoring } \\
\text { Treatments) } \\
\end{array}$ & 11 & $38.383 * *$ & $33.383 * *$ & $3339.912 * *$ & $\begin{array}{l}16.654^{*} \\
*\end{array}$ & $4.035^{* *}$ & $0.747 * *$ & $5.076 * *$ & $11.367 * *$ & $\begin{array}{l}53.927 * \\
*\end{array}$ & $\begin{array}{l}25.134 * \\
*\end{array}$ & $86.862 * *$ \\
\hline Checks & 3 & $40.076 * *$ & $51.028 * *$ & $11884.360 * *$ & $9.629 * *$ & $0.449 * *$ & 0.180 & $0.541 * *$ & $11.369 * *$ & $7.847 * *$ & $1.604 * *$ & $40.878 * *$ \\
\hline ERROR & 33 & 2.864 & 4.088 & 248.028 & 0.087 & 0.008 & 0.067 & 0.005 & 0.074 & 0.188 & 0.024 & 0.773 \\
\hline
\end{tabular}

$*, * *$ Significant at $5 \%$ and $1 \%$ probability level respectively

Table. 2 Range, mean, coefficient of variance and least significant differences for 11 characters of field pea genotypes

$\mathrm{LSD}_{1}=$ difference between adjusted yield of two genotype in the same block.

$\mathrm{LSD}_{2}=$ difference between two check means.

$\mathrm{LSD}_{3}=$ difference between adjusted mean of two genotypes in the different block.

$\mathrm{LSD}_{4}=$ difference between adjusted yield of genotype and check mean.

$\mathrm{PCV}=$ phenotypic coefficient of variance.

$\mathrm{GCV}=$ genotypic coefficient of variance .

\begin{tabular}{|c|c|c|c|c|c|c|c|c|c|}
\hline \multirow[t]{3}{*}{ Characters } & \multirow{3}{*}{$\begin{array}{l}\text { Range } \\
\text { (Min-Max) }\end{array}$} & \multirow{3}{*}{$\begin{array}{l}\text { Mean } \\
\text { Value }\end{array}$} & \multicolumn{3}{|c|}{ Coefficient of variance (\%) } & \multicolumn{4}{|c|}{ Range of parameters } \\
\hline & & & \multirow[t]{2}{*}{ PCV } & \multirow[t]{2}{*}{ GCV } & \multirow{2}{*}{$\begin{array}{l}\text { Coefficient of } \\
\text { variance (\%) }\end{array}$} & LSD $_{1}$ & $\mathrm{LSD}_{2}$ & $\mathrm{LSD}_{3}$ & $\mathrm{LSD}_{4}$ \\
\hline & & & & & & $5 \%$ & $5 \%$ & $5 \%$ & $5 \%$ \\
\hline $\begin{array}{l}\text { Days to } 50 \text { per cent } \\
\text { flowering }\end{array}$ & $61.188-77.938$ & 71.458 & 5.524 & 4.989 & 6.377 & 1.406 & 4.870 & 5.444 & 4.007 \\
\hline Days to maturity & $\begin{array}{l}111.875- \\
130.375\end{array}$ & 122.415 & 3.169 & 2.703 & 3.768 & 1.679 & 5.818 & 6.504 & 4.787 \\
\hline Plant height $(\mathrm{cm})$ & $\begin{array}{l}12.700- \\
139.650\end{array}$ & 74.659 & 35.597 & 28.690 & 38.197 & 13.081 & 45.313 & 50.662 & 37.286 \\
\hline $\begin{array}{l}\text { Number of primary } \\
\text { branches /plant }\end{array}$ & $0.718-2.697$ & 1.433 & 28.317 & 21.789 & 29.253 & 0.215 & 0.746 & 0.834 & 0.614 \\
\hline Number of pods/ plant & $10.885-26.060$ & 15.282 & 14.571 & 14.442 & 16.863 & 0.245 & 0.850 & 0.950 & 0.699 \\
\hline Number of seeds/ pod & $1.738-8.411$ & 4.261 & 30.460 & 30.414 & 34.181 & 0.060 & 0.207 & 0.231 & 0.170 \\
\hline Pod length $(\mathrm{cm})$ & $3.005-9.018$ & 5.293 & 22.786 & 22.720 & 25.659 & 0.076 & 0.263 & 0.294 & 0.216 \\
\hline 100 -seed weight $(\mathrm{g})$ & $10.872-27.432$ & 18.348 & 14.463 & 14.386 & 16.163 & 0.226 & 0.783 & 0.875 & 0.644 \\
\hline Biological yield/plant(g) & 15.999-38.913 & 26.101 & 15.047 & 14.955 & 17.107 & 0.360 & 1.247 & 1.394 & 1.026 \\
\hline Harvest index $(\%)$ & 23.039-61.684 & 43.405 & 17.639 & 17.522 & 19.795 & 0.730 & 2.530 & 2.828 & 2.082 \\
\hline Seed yield/plant(g) & $4.801-22.496$ & 11.554 & 28.906 & 28.874 & 32.606 & 0.129 & 0.448 & 0.501 & 0.369 \\
\hline
\end{tabular}


Table.3 Simple correlation coefficients between different characters in field pea genotypes

\begin{tabular}{|c|c|c|c|c|c|c|c|c|c|c|c|}
\hline Characters & $\begin{array}{l}\text { Days to } \\
50 \text { per } \\
\text { cent } \\
\text { flowering }\end{array}$ & $\begin{array}{c}\text { Days to } \\
\text { maturity }\end{array}$ & $\begin{array}{l}\text { Plant } \\
\text { height } \\
(\mathrm{cm})\end{array}$ & $\begin{array}{l}\text { Number } \\
\text { of } \\
\text { primary } \\
\text { branches } \\
\text { /plant }\end{array}$ & $\begin{array}{l}\text { Number } \\
\text { of pods } \\
\text { / plant }\end{array}$ & $\begin{array}{c}\text { Number } \\
\text { of seeds } \\
\text { / pod }\end{array}$ & $\begin{array}{l}\text { Pod } \\
\text { length } \\
(\mathrm{cm})\end{array}$ & $\begin{array}{c}\text { 100-Seed } \\
\text { weight }\end{array}$ & $\begin{array}{l}\text { Biological } \\
\text { yield/ } \\
\text { plant }\end{array}$ & $\begin{array}{c}\text { Harvest } \\
\text { index } \\
(\%)\end{array}$ & $\begin{array}{c}\text { Seed } \\
\text { yield/ } \\
\text { plant (g) }\end{array}$ \\
\hline $\begin{array}{l}\text { Days to } 50 \text { per } \\
\text { cent flowering }\end{array}$ & 1.0000 & $0.9412 * *$ & -0.1105 & -0.1376 & -0.1485 & -0.0499 & -0.0662 & 0.0176 & $-0.1773^{*}$ & -0.0624 & -0.1234 \\
\hline $\begin{array}{l}\text { Days to } \\
\text { maturity }\end{array}$ & & 1.0000 & -0.0885 & -0.1305 & -0.1466 & -0.0470 & -0.0678 & 0.0485 & $-0.1526^{*}$ & -0.0409 & -0.0998 \\
\hline Plant height(cm) & & & 1.0000 & $0.1887^{*}$ & $0.4387 * *$ & $-0.2515^{* *}$ & $-0.1829 *$ & $-0.1717 *$ & 0.0410 & $-0.2878 * *$ & -0.1487 \\
\hline Branches / plant & & & & 1.0000 & $0.4879 * *$ & $-0.2380 * *$ & $-0.1819 *$ & -0.0712 & 0.0836 & -0.1353 & -0.0498 \\
\hline Pods / plant & & & & & 1.0000 & $-0.4787 * *$ & $-0.4199 * *$ & -0.0946 & 0.0519 & $-0.2130^{* *}$ & -0.0958 \\
\hline Seeds / pod & & & & & & 1.0000 & $0.9287 * *$ & -0.0334 & $0.6719 * *$ & $0.7347 * *$ & $0.7952 * *$ \\
\hline Pod length(cm) & & & & & & & 1.0000 & -0.0503 & $0.6117 * *$ & $0.6696 * *$ & $0.7241^{* *}$ \\
\hline $\begin{array}{l}\text { 100-Seed } \\
\text { weight }(\mathrm{g})\end{array}$ & & & & & & & & 1.0000 & $0.1932 *$ & $0.4583^{* *} *$ & $0.3812^{* * *}$ \\
\hline $\begin{array}{l}\text { Biological yield/ } \\
\text { plant(g) }\end{array}$ & & & & & & & & & 1.0000 & $0.5598 * *$ & $0.8439 * *$ \\
\hline $\begin{array}{l}\text { Harvest index } \\
(\%)\end{array}$ & & & & & & & & & & 1.0000 & $0.9057 * *$ \\
\hline $\begin{array}{l}\text { Seed yield/plant } \\
\text { (g) }\end{array}$ & & & & & & & & & & & 1.0000 \\
\hline
\end{tabular}

*, **Significant at 5\% \& 1\% probability level Respectively.

Table.4 Direct and indirect effects of different characters on seed yield in fieldpea genotypes

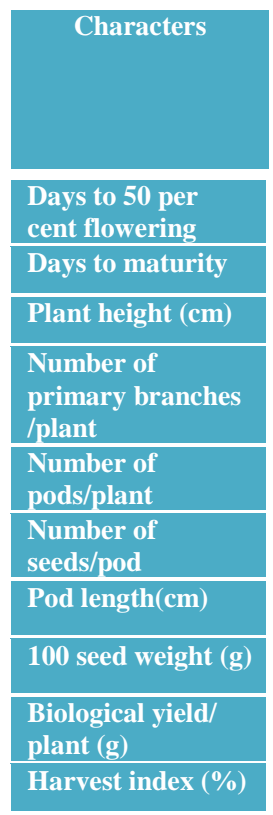

\begin{tabular}{|r|r|r|r|r|r|r|}
\hline $\begin{array}{c}\text { Days to 50 } \\
\text { per cent } \\
\text { flowering }\end{array}$ & $\begin{array}{c}\text { Days to } \\
\text { maturity }\end{array}$ & $\begin{array}{c}\text { Plant } \\
\text { height } \\
(\mathrm{cm})\end{array}$ & $\begin{array}{c}\text { Number } \\
\text { of } \\
\text { primary } \\
\text { branches } \\
\text { plant }\end{array}$ & $\begin{array}{c}\text { Number } \\
\text { of pods } \\
\text { plant }\end{array}$ & $\begin{array}{c}\text { Number } \\
\text { of seeds/ } \\
\text { pod }\end{array}$ & $\begin{array}{c}\text { Pod } \\
\text { length } \\
\text { (cm) }\end{array}$ \\
\hline $\mathbf{0 . 0 1 4 5}$ & 0.0137 & -0.0016 & -0.0020 & -0.0022 & -0.0007 & -0.0010 \\
\hline-0.0113 & $\mathbf{- 0 . 0 1 2 0}$ & 0.0011 & 0.0016 & 0.0018 & 0.0006 & 0.0008 \\
\hline-0.0011 & -0.0009 & $\mathbf{0 . 0 1 0 2}$ & 0.0019 & 0.0045 & -0.0026 & -0.0019 \\
\hline 0.0014 & 0.0013 & -0.0019 & $\mathbf{- 0 . 0 1 0 2}$ & -0.0050 & 0.0024 & 0.0018 \\
\hline-0.0097 & -0.0096 & 0.0287 & 0.0319 & $\mathbf{0 . 0 6 5 4}$ & -0.0313 & -0.0275 \\
\hline-0.0068 & -0.0064 & -0.0342 & -0.0324 & -0.0651 & $\mathbf{0 . 1 3 6 0}$ & 0.1263 \\
\hline 0.0013 & 0.0013 & 0.0036 & 0.0035 & 0.0082 & -0.0181 & $-\mathbf{0 . 0 1 9 5}$ \\
\hline 0.0008 & 0.0023 & -0.0081 & -0.0034 & -0.0045 & -0.0016 & -0.0024 \\
\hline-0.0769 & -0.0662 & 0.0178 & 0.0363 & 0.0225 & 0.2915 & 0.2654 \\
\hline-0.0356 & -0.0233 & -0.1641 & -0.0772 & -0.1214 & 0.4189 & 0.3818 \\
\hline
\end{tabular}

\begin{tabular}{|c|c|c|c|}
\hline $\begin{array}{c}\text { 100-Seed } \\
\text { weight } \\
(\mathrm{g})\end{array}$ & $\begin{array}{c}\text { Biological } \\
\text { yield / } \\
\text { plant(g) }\end{array}$ & $\begin{array}{c}\text { Harvest } \\
\text { index } \\
(\%)\end{array}$ & \multicolumn{1}{|c|}{$\begin{array}{c}\text { Seed yield / } \\
\text { plant(g) }\end{array}$} \\
\hline 0.0003 & -0.0026 & -0.0009 & -0.1234 \\
\hline-0.0006 & 0.0018 & 0.0005 & -0.0998 \\
\hline-0.0017 & 0.0004 & -0.0029 & -0.1487 \\
\hline 0.0007 & -0.0008 & 0.0014 & -0.0498 \\
\hline-0.0062 & 0.0034 & -0.0139 & -0.0958 \\
\hline-0.0045 & 0.0914 & 0.0999 & 0.7952 \\
\hline 0.0010 & -0.0119 & -0.0131 & 0.7241 \\
\hline $\mathbf{0 . 0 4 7 1}$ & 0.0091 & 0.0216 & 0.3812 \\
\hline 0.0838 & $\mathbf{0 . 4 3 3 9}$ & 0.2429 & 0.8439 \\
\hline 0.2613 & 0.3192 & $\mathbf{0 . 5 7 0 2}$ & $\mathbf{0 . 9 0 5 7}$ \\
\hline
\end{tabular}

R SQUARE $=0.9867$, Residual factor $=0.1151$, Bold figures indicate the direct effects 
Correlation coefficients were worked out for different yield contributing characters in field pea (Pisum sativum L. var. arvense) genotypes (Table 3). The genotypic correlation coefficients between different characters were generally similar in sign and nature to the corresponding phenotypic correlation coefficients. However, in general the magnitudes of genotypic correlation coefficient were higher than their corresponding phenotypic correlation coefficient which suggested, a strong inherent relationship in different pair of characters. Similar, results have also been reported by Kumar et al., (2003), Chaudhary and Sharma (2003) and Singh et al., (2014). Seed yield per plant exhibited highly significant and positive correlation with harvest index followed by biological yield per plant, seeds per pod, pod length and 100-seed weight. However, seed yield per plant had negative and nonsignificant correlation with plant height followed by days to 50 per cent flowering, days to maturity, pods per plant and number of primary branches per plant. Singh et al., (2014) also reported that biological yield per plant was highly significant with grain yield per plant. Earlier reports in fieldpea have also indicated existence of positive and highly significant association of weight of seeds per plant with the weight of pods per plant, biological weight per plant and harvest index recording $(0.839,0.694$ and 0.505$)$, respectively (Tofiq et al., 2015). In addition Basaiwala et al., (2013) also found that seed yield per plant was positively and significantly correlated with seeds per pod and harvest index. Another report in fieldpea also indicated that length and width of pod and 100-seed weight were associated positively and significantly with grain yield per plant (Singh et al., 2008).

The direct and indirect effects of different characters on seed yield per plant are presented in Table 4. High positive direct contributions to seed yield per plant was exhibited by harvest index and biological yield per plant. However, seeds per pod, pods per plant, 100 -seed weight, days to 50 per cent flowering and plant height exhibited considerable positive and direct effect on seed yield per plant. Tofiq et al., (2015) also reported that biological weight per plant and harvest index exhibited maximum positive direct effect on weight of seeds per plant recording (0.630 and 0.456) respectively. Singh et al., (2014) also reported that biological yield per plant, harvest index and plant height had positive and direct effect on grain yield per plant.

Similarly, days to 50 per cent flowering and pod length had positive and direct effect on grain yield per plant. Bashir et al., (2017) also reported that 100-seed weight and number of seeds per pod had maximum direct effect on grain yield per plant. The occurrence of negative as well as positive indirect effects on seed yield by one or more characters present a complex situation where a compromise balance is required to attain proper balance of different yield components, for determining the ideotype of seed yield in field pea.

All over analysis indicated that high amount of variability was present in the genotypes under study which provides a better opportunity to select desirable genotypes for further utilization in breeding programme. Correlation and path analysis indicated that harvest index, biological yield per plant, number of seeds per pod, pod length and 100seed weight, had true relationship with seed yield and they are the major yield contributing traits.

Hence, direct selection for these traits would be rewarding for yield improvement in field pea. Results obtained by Basaiwala et al., (2013), Bashir et al., (2017) have also in agreement with this finding. 


\section{References}

Basaiwala, P., Rastogi, N. K. and Parikh, M. 2013.Genetic variability and character association in field pea (Pisum sativum L.) genotypes. Asian Journal of Horticulture, 8(1): 288-291.

Bashir, I., Ishtiaq, S., Fiaz, S. and Sajjad, M. 2017.Association of yield attributing traits in pea (Pisum sativum L.) Germplasm. Banat's Journal of Biotechnology, 8(15): 43-49.

Beale, E. M. L. 1969. Euclidean cluster analysis. A paper contributed to $37^{\text {th }}$ session of the International Statistical Institute.

Burton, G. W. and de Vane, E. W. 1953. Estimating heritability in tall fescue (Festuca arundincea) from replicated clonal material. Agron. J., 45: 178-181.

Chaudhary, D. K. and Sharma, R. R. 2003.Genetic variability, correlation and path analysis for green pod yield and its components in garden pea. Indian Journal of Horticulture, 60(3): 251-256.

Dewey, D. R. and Lu, K. H. 1959.Correlation and path coefficient analysis of yield components of crested wheat grass and seed production. J. Agron., 57: 515 - 518.

Federer, W. T. 1956. Augmented designs, "Hawain Planters". Record, 55: 191-208.

Khan, M. R. A., Mahmud, F., Reza, M. A., Mahbub, M. M., Shirazy, B. J. and Rahman, M. M. 2017. Studies on Genetic Diversity, Correlation and Path Analysis for Yield and Yield Components of Pea (Pisum sativum L.). World Journal of Agricultural Sciences, 13(1): 11-16.

Kumar, B. 2008.Studies on Variability, heritability and genetic advance in pea
(Pisum sativum L.). International Journal of Plant Sciences, 3(1): 211-212.

Kumar, B., Ram, L.,Singh, J. D. and Singh, B. 2003. Correlations and path coefficient analysis in pea (Pisum sativum L.). Prog.Agric., 3(1/2): 141-142.

Meena, B. L., Das, S. P., Meena, S. K., Kumari, R., Devi, A. G. and Devi, H. L. 2017. Assessment of GCV, PCV, heritability and genetic advance for yield and its components in field pea (Pisum sativum L.). International Journal of Current Microbiology and Applied Sciences, 6(5): 1025-1033.

Pal, A. K. and Singh, S. 2012.Correlation and path analysis in garden pea (Pisum sativum L. var. hortense). Asian J. Hort., 7(2): 569-573.

Ranjan, S., Kumar, M. and Pandey, S. S. 2006.Genetic variability in peas (Pisum sativum L.). Legume Research, 29(4): 311312.

Searle, S. R. 1961. Phenotypic, Genotypic and Environmental correlations, Biometrics, 17: 474-480.

Singh, A., Lavanya, G. and Roopa 2014.Character association studies in fieldpea (Pisum sativum L.), Technology and Sciences Indian Journals, 1: 51-53.

Singh, V. S., Rai, G. and Mishra, A. 2008.Correlation and path analysis in fieldpea. Plant Archives, 8(2): 859 - 860.

Spark, D. N. 1973. Euclidean cluster analysis: Algorithm As.-58 Applied Statistics, 22: 126136.

Tofiq, S. E., Abdul khaleq, D. A., Amin, T. N. H. and Azez, O. K. 2015. Correlation and path coefficient analysis in seven field pea (Pisum sativum L.). International Journal of Plant, Animal and Environment Sciences, 5(4): 2231-4490.

\section{How to cite this article:}

Kanhaiya Lal, Rajesh Kumar, Shiv Prakash Shrivastav, Ashok Kumar and Yogendra Singh. 2018. Genetic Variability, Character Association and Path Analysis of Seed Yield and Its Contributing Traits in Field pea (Pisum sativum L. var. arvense). Int.J.Curr.Microbiol.App.Sci. 7(06): 1815-1820. doi: https://doi.org/10.20546/ijcmas.2018.706.216 